\title{
The Incorporation of Chromium in Rice Straw Fermented with Ganoderma lucidum
}

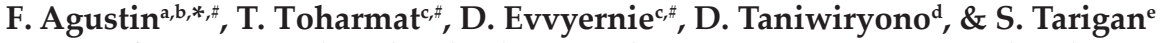 \\ ${ }^{a}$ Department of Nutrition and Feed Technology, Graduate Program, Bogor Agricultural University

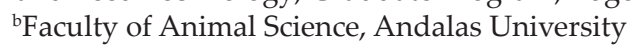 \\ Kampus Limau Manis Padang, Indonesia \\ 'Department of Nutrition and Feed Technology, Faculty of Animal Science, Bogor Agricultural University \\ dIndonesian Biotechnology Research Institute for Estate Crops \\ Jln. Salak No. 1, Bogor, Indonesia

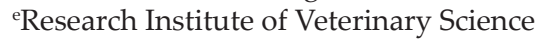 \\ Jln. R.E. Martadinata 30, PO Box 151, Bogor, 16114, Indonesia \\ "Jln. Agatis, Kampus IPB Dramaga Bogor 16680, Indonesia \\ (Received 31-10-2012; Reviewed 12-01-2013; Accepted 01-04-2013)
}

\begin{abstract}
The research was designed to evaluate chromium incorporation by Ganoderma lucidum in rice straw substrate supplemented with chromium chloride. Treatments were combination of Cr level (0, $500,1000,1500,2000,25000$, and $3000 \mathrm{ppm})$ and fermentation time $(0,2,3$, and $4 \mathrm{wk})$. The treatments were arranged in a factorial $7 \times 4$ and allocated in completely randomized design with three replications. G. lucidum was grown in potato dextrose agar (PDA) medium for $\mathbf{1 0}$ days and was inoculated to the substrate which have been sterilized and mixed with $\mathrm{CrCl}_{3} \cdot 6 \mathrm{H}_{2} \mathrm{O}$. The moisture of substrate was maintained at $70 \%$. Fiber and protein components of growth media of G. lucidum was determined and analyzed for their $\mathrm{Cr}$ content. The finding result showed that addition of $\mathrm{Cr}$ up to $3000 \mathrm{ppm}$ into the substrate stimulated the G. lucidum growth. Chromium was incorporated into the fiber and protein components of the growth substrate of G. lucidum during fermentation. Incorporation of Cr into the protein of substrate containing $3000 \mathrm{ppm} \mathrm{Cr}$ was highest when fermented for $4 \mathrm{wk}$. Protein component of substrate contained $9.29 \% \mathrm{Cr}$ while in NDF and ADF was $27.20 \%$ and $10.55 \% \mathrm{Cr}$, respectively. It is concluded that $\mathrm{Cr}$ was incorporated into the $\mathrm{G}$. lucidum cells during fermentation.
\end{abstract}

Key words: chromium, Ganoderma lucidum, incorporation, rice straw

\section{ABSTRAK}

Penelitian dirancang untuk mengevalusi inkorporasi kromium oleh fungi Ganoderma lucidum pada substrat jerami padi yang ditambah dengan khromium khlorida, Perlakuan pada penelitian ini adalah kombinasi kadar chromium $(0,500,1000,1500,2000,2500$, dan 3000 ppm) dengan lama fermentasi $(0,2$, 3, dan 4 minggu). Perlakuan dirancang dengan menggunakan pola faktorial $(7 \times 4)$ yang dialokasikan dalam rancangan acak lengkap dengan tiga ulangan. Starter G. lucidum ditumbuhkan pada media PDA (potato dextrose agar) selama 10 hari dan dinokulasikan pada substrat yang telah ditambah dengan $\mathrm{CrCl}_{3} \cdot 6 \mathrm{H}_{2} \mathrm{O}$ dan diautoclave. Kadar air substrat ditetapkan $70 \%$. Komponen serat dan protein dari media pertumbuhan G. lucidum ditentukan dan dianalisa kandungan Cr-nya. Hasil penelitian menunjukkan bahwa penambahan $\mathrm{Cr}$ sampai $3000 \mathrm{ppm}$ pada substrat merangsang pertumbuhan G. lucidum. Kromium terinkorporasi ke dalam komponen serat dan protein pada substrat pertumbuhan $\mathrm{G}$. lucidum. Inkorporasi $\mathrm{Cr}$ ke dalam protein substrat yang mengandung $3000 \mathrm{ppm} \mathrm{Cr}$ dan difermentasi selama 4 minggu lebih tinggi dibandingkan kadar lainnya. Komponen protein mengandung 9,29\% Cr sedangkan di dalam NDF and ADF masing-masing adalah $27,20 \%$ dan $10,55 \% \mathrm{Cr}$. Dapat disimpulkan bahwa Cr terinkorporasi ke dalam sel miselium G. lucidum selama fermentasi.

Kata kunci: chromium, Ganoderma lucidum, inkorporasi, jerami padi 


\section{INTRODUCTION}

Chromium $(\mathrm{Cr})$ is one of the micro mineral and its essentiality has been proved in many researches. Chromium is important for animals (NRC, 1997) because of their role in the metabolism of carbohydrates, fats, proteins and nucleic acids (Pechova \& Pavlata, 2007). Chromium from inorganic sources is poorly absorbed. The conversion of inorganic $\mathrm{Cr}$ to an organic complex improves its bioavailability (NRC 1997; Pechova \& Pavlata, 2007). Supplementation of mixed $\mathrm{Cr}$ in fermented feed and G. lucidum improved immune response of lactating cows (Agustin et al., 2011). Therefore, efforts should be made to convert inorganic $\mathrm{Cr}$ to organic form. Effective Cr level for G. lucidum growth in solid state fermentation of oil palm by-product was $3000 \mathrm{ppm}$ with incorporation value of $68.23 \%$ (Agustin et al., 2010). Metal ions including $\mathrm{Cr}$ can accumulate intracellularly in fungal cells (Sen \& Dastidar, 2010). The ability of microorganism cell to bind metal ions is associated with its cell wall (Shugaba et al., 2012).

Ganoderma lucidum is a species of Basidiomycetes that can utilize fiber as a substrate for its growth (Chang \& Miles, 2004). G. lucidum which belongs to the white rot fungi can produce extracellular enzymes laccase, which has a high ligninolytic activity (Baldrian, 2003; Chang \& Miles, 2004; Mtui \& Nakamura, 2007; Ke et al., 2011). The fungi are able to tolerate the toxic effects of hexavalent Cr (Prasenjit \& Sumathi, 2005; Shugaba et al., 2012) and generally show greater resistance to metal ion concentration than many bacterial species (Oliver et al., 2005; Ezzouhri et al., 2009; Sen \& Dastidar, 2010).

G. lucidum is able to use sawdust as a substrate for its growth (Chang \& Miles, 2004) and it can also use oil palm by product for its growth (Agustin et al., 2010). A source of fiber such as rice straw is available and its availability is abundant. Rice straw may meet the criteria as a source of fiber for G. lucidum growth. Misra et al., (2007) reported that mustard straw fermented by $G$. lucidum at a temperature of $35^{\circ} \mathrm{C}$ for $21 \mathrm{~d}$ can increase in vitro digestibility and delignification. G. lucidum can bind and can accumulate metal ions intracellularly. However, information about the use of rice straw as a growth medium of G. lucidum for the purpose of producing organic $\mathrm{Cr}$ have not available yet. The experiment was designed to determine the incorporation of $\mathrm{Cr}$ by G. lucidum in rice straw as a main component of substrate. The result obtained is an effort to synthesize organic $\mathrm{Cr}$ to be used as a mineral supplement for livestock. In this case the whole fermented substrate is used as the product.

\section{MATERIALS AND METHODS}

\section{Preparation Starter of Ganoderma lucidum}

Inoculum stock of G. lucidum was obtained from the collection of Indonesian Biotechnology Research Institute for Estate Crops (IBRI), Bogor. Starter was obtained by rejuvenating inoculums stock at IBRI Microbial Laboratory and Laboratory of Microbiology, Department of Nutrition and Feed Technology, Faculty of Animal Science, Bogor Agricultural University. The rejuvenation of inoculums was carried out by culturing isolates of stock culture G. lucidum into petridish containing PDA medium (potato-dextrose-agar) (Wagner et al., 2003), and was incubated for $10 \mathrm{~d}$ or until the mycelium of G. lucidum met petridish. The production of the inoculums was a crucial step affecting significantly the performance of the subsequent fermentation.

\section{Substrate Preparation and Inoculation}

The main material used in this research was derived from rice straw obtained from rice fields. Rice straw was chopped to the size of $2-3 \mathrm{~cm}$ and dried in the sun to the moisture content of about $10 \%$. Rice straw was mixed with a solution containing $\mathrm{CrCl}_{3} \cdot 6 \mathrm{H}_{2} \mathrm{O}$ with varying $\mathrm{Cr}$ concentration: 0, 500, 1000, 1500, 2000, 2500, and $3000 \mathrm{mg} \mathrm{Cr}$ per $\mathrm{kg}$ of dry matter and conditioned at $70 \%$ moisture content. The mixed substrate was inserted into the $300 \mathrm{ml}$ bottle, covered with aluminum foil, and sterilized for $30 \mathrm{~min}$ at pressure of 1.2 and temperature of $121{ }^{\circ} \mathrm{C}$. After cooling, sterilized bottle were inoculated with starter aseptically with a plug diameter of $0.5 \mathrm{~cm}$ in the laminar flow cabinet. The inoculated substrate was incubated at $27-28{ }^{\circ} \mathrm{C}$ for $0,2,3$, or 4 wk. Fermentation products were harvested according to the time of incubation.

\section{Experimental Design}

The experiment was carried out in a $7 \times 4$ factorial design with 3 replications for each treatment. There were seven levels of $\mathrm{Cr}$ supplemented into the rice straw, i.e. 0, 500, 1000, 15000, 1500, 2000, 2500, and 3000 ppm, at the time factor. There were four fermentation times as the second factor, i.e. 0, 2, 3, and $4 \mathrm{wk}$.

\section{Sample and Data Analysis}

Percentage of dry matter (DM) and organic matter (OM) loss were calculated. Total $\mathrm{Cr}$ in the fermented biomass was measured by using Atomic Absorption Spectrophotometer (AAS) Shimadzu AA680 models (Carry \& Allaway, 1971). The amount of Cr bound fiber and protein components of biomass was measured separately. Measurement of total $\mathrm{Cr}$ in solid substrate was conducted by using a sample of $5 \mathrm{~g}$. Samples were crushed in a mortal porcelain and put into a test tube, add $5 \mathrm{~mL}$ of $10 \%$ TCA and was homogenized with a vortex, and then allowed to stand for one hour. The solution was then centrifuged at $3000 \mathrm{rpm}$ for $10 \mathrm{~min}$. Chromium concentration in supernatant was measured. The content of the neutral detergent fiber fraction of fiber (NDF) and acid detergent fiber (ADF) were determined by analysis of Van Soest (Van Soest \& Wine 1967). Levels of $\mathrm{Cr}$ contained in the NDF and ADF are determined from the sample after the determination of NDF and ADF. Biomass protein content was analyzed (Bradford 1976) and its $\mathrm{Cr}$ levels were measured.

The data were analyzed statistically according to two-way Analysis of Variance (ANOVA) and the difference between treatment means was determined using Duncan's Multiple Range Test (DMRT). 


\section{RESULTS AND DISCUSSION}

G. lucidum grew rapidly on PDA on the fifth until $10 \mathrm{~d}$ of incubation. The mycelium reached maximum growth on stable condition when the level of water was $70 \%$. The water content of the rice straw substrate in this study was higher than recommended by Chang \& Miles (2004) which was $60 \%-65 \%$. This is because the substrate for cultivation of G. lucidum was different. Chang \& Miles (2004) used saw dust as a substrate, while in this study we used rice straw as a main component of substrate. The growth of G. lucidum varied widely, depending on the kind of substrate (Erkel, 2009). Fermentation with G. lucidum was carried out at temperatures ranged from $26-28{ }^{\circ} \mathrm{C}$ and $\mathrm{pH}$ of substrate 5.5. The optimum fermentation condition appeared to depend on temperature and $\mathrm{pH}$, and this substrate conditions was suitable for the growth of G. lucidum according to the recommendation of Chang \& Miles (2004). The growth of fungi G. lucidum on rice straw substrate containing up to 3000 ppm $\mathrm{Cr}$ began to appear after the age of $1 \mathrm{wk}$. After 2 wk of fermentation, its white mycelium had covered half of the substrate surface of the media in the bottle. Mycelium growth in 3000 ppm Cr levels up to 4 wk of incubation was excellent but has not formed fruiting bodies.

\section{Dry Matter and Organic Matter Content of Fermented Rice Straw}

Dry matter content of fermented rice straw was influenced by the fermentation time and $\mathrm{Cr}$ levels $(\mathrm{P}<0.01)$ but there was no interaction between the two factors (Table 1). Dry matter content declined sharply in the second week of fermentation, from $29.24 \%$ to $26.5 \%$, suggesting that the nutrients contained in the substrate has been used by fungi.

Dry matter content of substrate continued to decrease up to $4 \mathrm{wk}$ of incubation. It was suggested that the nutrients in rice straw was used by G. lucidum to increase the number of cells as indicated by the growth of mycelium. There was a linear relationship between the dry matter content of rice straw media with fermentation time according to the equation, $\mathrm{Y}=-1.11 \mathrm{X}+29.70\left(\mathrm{R}^{2}\right.$ $=0.8053, \mathrm{P}<0.01$ where $\mathrm{Y}=$ change in the levels of dry matter, \%; $X=$ length of fermentation, days). This means that as the fermentation time increased by one unit there was a reduction of dry matter by $1.11 \%$. Ligninolytic enzyme produced by G. lucidum degraded lignin from the rice straw, and this was associated with fermentation time and the reduce of dry matter. Product of degraded lignin was used by G. lucidum to its mycelium growth.

Chromium supplementation appeared to decrease the rate of decline in dry matter content of rice straw substrate. Slowing decline in dry matter content of rice straw occurred at 1500 ppm Cr levels up to 3000 ppm. It is expected that high levels of $\mathrm{Cr}$ inhibits the growth of G. lucidum so that decomposition of organic material into $\mathrm{H}_{2} \mathrm{O}$ and $\mathrm{CO}_{2}$ slowed and ultimately decreased the proportion of dry matter of fermented rice straw. However, mycelium growth was not impaired as it was observed that mycelium growth covered the media even at $\mathrm{Cr}$ levels of $3000 \mathrm{ppm}$.

The rate of change in the content of organic matter of fermented rice straw was similar to that of dry matter, which was somewhat influenced by fermentation time and $\mathrm{Cr}$ levels $(\mathrm{P}<0.01)$ (Figure 1$)$. A decline in organic matter content was observed with increasing duration of fermentation from 0 to $4 \mathrm{wk}$. The decline of organic matter content was from $23.95 \%$ to $19: 55 \%$ in fermentation time of $4 \mathrm{wk}$. Oxidases such as laccase from G. lucidum are enzymes which were involved in oxidative conversions of organic compounds and materials (Mtui, 2012).

This result showed that the proportion of inorganic materials with organic media remains the same for all the different levels of $\mathrm{Cr}$. It is thought that the formation of organic matter occurred in the form of mycelium and was comparable to the decreasing levels of organic matter or dry matter content.

\section{The Loss of Dry Matter and Organic Matter in Fermented Rice Straw}

The loss of dry matter and organic matter in fermented rice straw was significantly increased $(P<0.01)$ with increasing length of fermentation time. There was

Table 1. The persentage of dry matter content fermented with Ganoderma lucidum on rice straw with Cr levels 0-3000 ppm and fermentation time $0,2,3,4 \mathrm{wk}$

\begin{tabular}{|c|c|c|c|c|c|}
\hline \multirow{2}{*}{$\begin{array}{l}\text { Cr level } \\
\text { (ppm) }\end{array}$} & \multicolumn{4}{|c|}{ Fermentation time (Wk) } & \multirow{2}{*}{ Average } \\
\hline & 0 & 2 & 3 & 4 & \\
\hline 0 & $29.27 \pm 0.31$ & $26.66 \pm 0.49$ & $25.27 \pm 0.23$ & $24.87 \pm 1.35$ & $26.52 \pm 1.91^{\mathrm{a}}$ \\
\hline 500 & $28.75 \pm 0.63$ & $26.72 \pm 0.67$ & $25.84 \pm 0.27$ & $24.57 \pm 0.85$ & $26.46 \pm 1.68^{\mathrm{a}}$ \\
\hline 1,000 & $28.80 \pm 0.86$ & $25.29 \pm 0.47$ & $25.85 \pm 0.28$ & $25.25 \pm 0.24$ & $26.30 \pm 1.59^{a}$ \\
\hline 1,500 & $29.86 \pm 0.63$ & $26.72 \pm 0.73$ & $26.81 \pm 2.01$ & $25.29 \pm 2.08$ & $27.17 \pm 2.17^{\mathrm{b}}$ \\
\hline 2,000 & $29.02 \pm 0.40$ & $26.54 \pm 0.63$ & $26.35 \pm 0.80$ & $26.04 \pm 0.74$ & $26.99 \pm 1.36^{b}$ \\
\hline 2,500 & $29.09 \pm 0.65$ & $26.69 \pm 0.27$ & $26.44 \pm 0.58$ & $26.01 \pm 0.79$ & $27.06 \pm 1.35^{\mathrm{b}}$ \\
\hline 3,000 & $29.90 \pm 0.50$ & $26.89 \pm 0.21$ & $27.85 \pm 0.98$ & $27.10 \pm 0.01$ & $27.93 \pm 1.33^{c}$ \\
\hline Average & $29.24 \pm 0.67^{c}$ & $26.50 \pm 0.68^{b}$ & $26.34 \pm 1.11^{\mathrm{b}}$ & $25.59 \pm 1.21^{\mathrm{a}}$ & \\
\hline
\end{tabular}

Note: Means in the same row or column with different superscript differ significantly $(\mathrm{P}<0.01)$. 


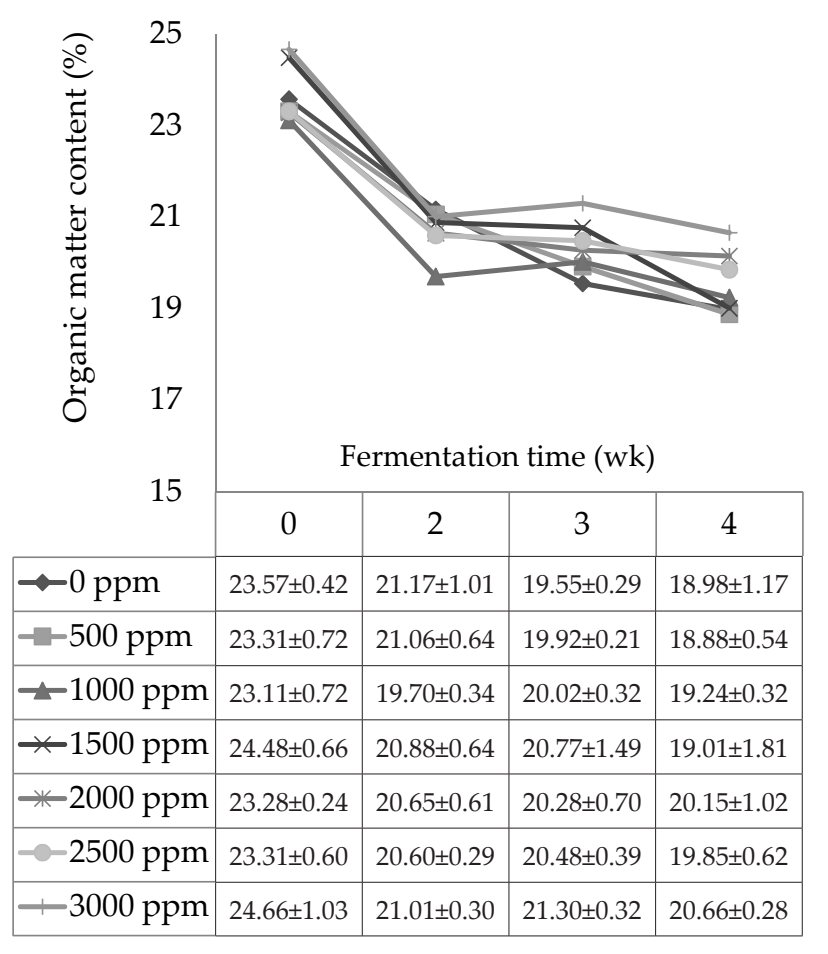

Figure 1. Curves percentage of organic matter content fermented with Ganoderma lucidum on rice straw substrate with Cr levels $0(-\bullet-), 500(-\boldsymbol{m}-), 1000(-\boldsymbol{\Delta}-), 1500(-\mathrm{x}-)$, $2000(-*-), 2500(-\bullet-)$, and $3000(-\mid-)$ ppm and fermentation time $0,2,3$, and $4 \mathrm{wk}$.

no interaction between the fermentation periods with $\mathrm{Cr}$ levels (Table 2). Dry matter loss in rice straw increased with increasing duration of fermentation, followed by growth of the mycelium which filled the surface of the substrate and covered the growing medium. Dry matter loss begins in $2 \mathrm{wk}(12.49 \%)$ and continued to increase up to $4 \mathrm{wk}(17.19 \%)$. This condition suggests that with increasing dry matter loss, more nutrients were utilized by G. lucidum for the metabolism and growth of its mycelium. There was a linear relationship between the dry matter loss to the fermentation time of fermented rice straw by following equation: $Y=5.356 X-2.35\left(R^{2}=0.83\right.$, $\mathrm{P}<0.01$ where $\mathrm{Y}=$ dry matter loss, $\%, \mathrm{X}=$ length of fermentation, week), but rate of dry matter loss decreases with increasing $\mathrm{Cr}$ at a level of more than 2000 ppm Cr. This suggests that the levels of more than $2000 \mathrm{ppm} \mathrm{Cr}$ decreased the growth rate of G. lucidum. In our research, the dry matter loss in fermented rice straw have the different profile with the dry matter loss in oil palm byproduct fermented with G. lucidum. In contrast, in case of oil palm by-product, the increase of $\mathrm{Cr}$ level in substrate up to $3000 \mathrm{ppm} \mathrm{Cr}$ did not affect the growth rate of G. lucidum (Agustin et al., 2010). The loss of dry matter on cultivation of oyster mushroom in wheat straw substrate was 9.4\% (Pant et al., 2006), while in this study, the loss of dry matter was $17.19 \%$. This difference in result could be due to G. lucidum being a white rot fungus which is capable of producing ligninolytic enzyme (laccase, manganese peroxidase, lignin peroxidase) (Ke et al., 2011) and able to degrade fiber components of rice straw.

The pattern of organic matter loss was the same with the dry matter loss in fermented rice straw in relation to fermentation time and levels of $\mathrm{Cr}$ in media. Means of organic matter loss in fermented rice straw was influenced by the fermentation time $(\mathrm{P}<0.01)$ and $\mathrm{Cr}$ levels $(\mathrm{P}<0.05)$. There was no interaction between $\mathrm{Cr}$ levels with long fermentation (Figure 2). Organic matter loss begins at week $2(14.97 \%)$ and continued to increase until at week 4 fermentation period (21.88\%). Increasing the rate of organic matter loss in rice straw showed an increase in the amount of nutrients utilized by G. $l u$ cidum for its metabolic activity and its cell growth.

At the early stage of fermentation, G. lucidum utilized the digestible nutrients contained in rice straw, after which the fungus utilized structural carbohydrates, especially complex compounds that are bound together with lignin. G. lucidum produces laccase enzyme which is capable of hydrolyzing lignin binding with other compounds (Baldrian, 2003; Ke et al., 2011). Increased organic matter loss decreased with increasing fermentation time. These results indicated that G. lucidum was able to hydrolyze and utilize structural carbohydrates and lignin.

Table 2. The loss of dry matter of Ganoderma lucidum fermentation product (\%) on rice straw substrate with Cr levels 0-3000 ppm and fermentation time $0,2,3,4 \mathrm{wk}$

\begin{tabular}{cccccc}
\hline $\begin{array}{c}\text { Cr level } \\
(\mathrm{ppm})\end{array}$ & \multicolumn{2}{c}{ Fermentation time $(\mathrm{Wk})$} & Average \\
\cline { 2 - 5 } & 0 & 2 & 3 & $20.12 \pm 4.62$ & $12.35 \pm 8.36^{\mathrm{b}}$ \\
\hline 0 & 0 & $11.96 \pm 2.45$ & $17.31 \pm 0.98$ & $19.26 \pm 4.69$ & $10.97 \pm 7.98^{\mathrm{b}}$ \\
1,000 & 0 & $10.05 \pm 4.15$ & $14.59 \pm 2.64$ & $16.52 \pm 2.24$ & $11.33 \pm 7.19^{\mathrm{b}}$ \\
1,500 & 0 & $14.95 \pm 3.81$ & $13.85 \pm 1.58$ & $20.77 \pm 5.30$ & $12.31 \pm 8.78^{\mathrm{b}}$ \\
2,000 & 0 & $13.31 \pm 1.19$ & $15.19 \pm 6.76$ & $15.17 \pm 1.28$ & $10.35 \pm 6.76^{\mathrm{a}}$ \\
2,500 & 0 & $11.31 \pm 2.26$ & $14.93 \pm 4.02$ & $14.63 \pm 1.62$ & $9.63 \pm 6.21^{\mathrm{a}}$ \\
3,000 & 0 & $11.21 \pm 2.28$ & $12.67 \pm 3.15$ & $13.87 \pm 0.79$ & $9.88 \pm 7.10^{\mathrm{a}}$ \\
Average & 0 & $14.64 \pm 8.10$ & $11.00 \pm 2.24$ & $17.19 \pm 4.43^{\mathrm{c}}$ & \\
\hline
\end{tabular}

Note: Means in the same row or column with different superscript differ significantly $(\mathrm{P}<0.01)$. 


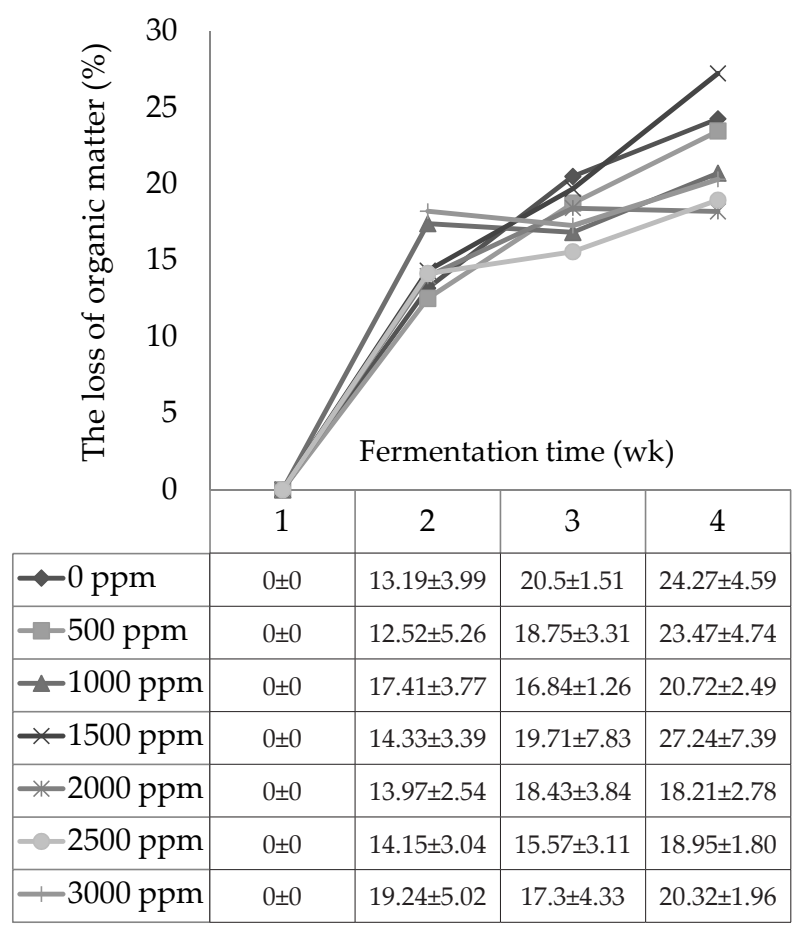

Figure 2. The loss of organic matter of Ganoderma lucidum fermentation product $(\%)$ on rice straw substrate with $\mathrm{Cr}$ levels $0(-\bullet-), 500(-\boldsymbol{m}-), 1000(-\boldsymbol{\Delta}-), 1500(-x-), 2000(-*-)$, $2500(-\bullet-)$, and $3000(-1-)$ ppm and fermentation time $0,2,3$, and $4 \mathrm{wk}$.

\section{Cr Incorporation in Fermented Products}

The element $\mathrm{Cr}$ bound in media was probability bound with media components and was converted into mycelial cell component of G. lucidum. Chromium incorporation into the cell of G. lucidum (Figure 3) is thought to occur because it grew well in the rice straw substrate. The binding and incorporation of $\mathrm{Cr}$ was significantly affected $(\mathrm{P}<0.01)$ by the $\mathrm{Cr}$ levels of substrate. There was no interaction between $\mathrm{Cr}$ levels with fermentation time. G. lucidum using $\mathrm{Cr}$ together with the use of organic matter of rice straw fiber components. This was indicated by the amount of $\mathrm{Cr}$ bound and incorporated in fermentation product. Incorporated $\mathrm{Cr}$ in fermentation product of G. lucidum was increase along with the higher $\mathrm{Cr}$ levels in substrate. The binding and incorporation of $\mathrm{Cr}$ in $\mathrm{Cr}$ levels of 1000 ppm was only 120 ppm Cr. The amount of incorporated $\mathrm{Cr}$ increase continuously until its value $1410.82 \mathrm{ppm} \mathrm{Cr}$ at the $\mathrm{Cr}$ levels of $3000 \mathrm{ppm}$ based on dry matter. There was a linear relationship between the binding and incorporation of $\mathrm{Cr}$ with a $\mathrm{Cr}$ content of the substrate following the equation: $\mathrm{Y}=$ 296.72X - $471.86\left(\mathrm{R}^{2=} 0.98, \mathrm{P}<0.01\right.$ where $\mathrm{Y}=\mathrm{Cr}$ bound, $\% ; X=C r$ content of the media, $500 \mathrm{ppm})$. This result showed that G. lucidum was more resistance to supplementation of $\mathrm{Cr}$ in high concentration because mycelia growth gave the organism a larger surface area, which provides greater protection to sensitive organelles of the fungi. In addition, fungi are eukaryotic cells, which

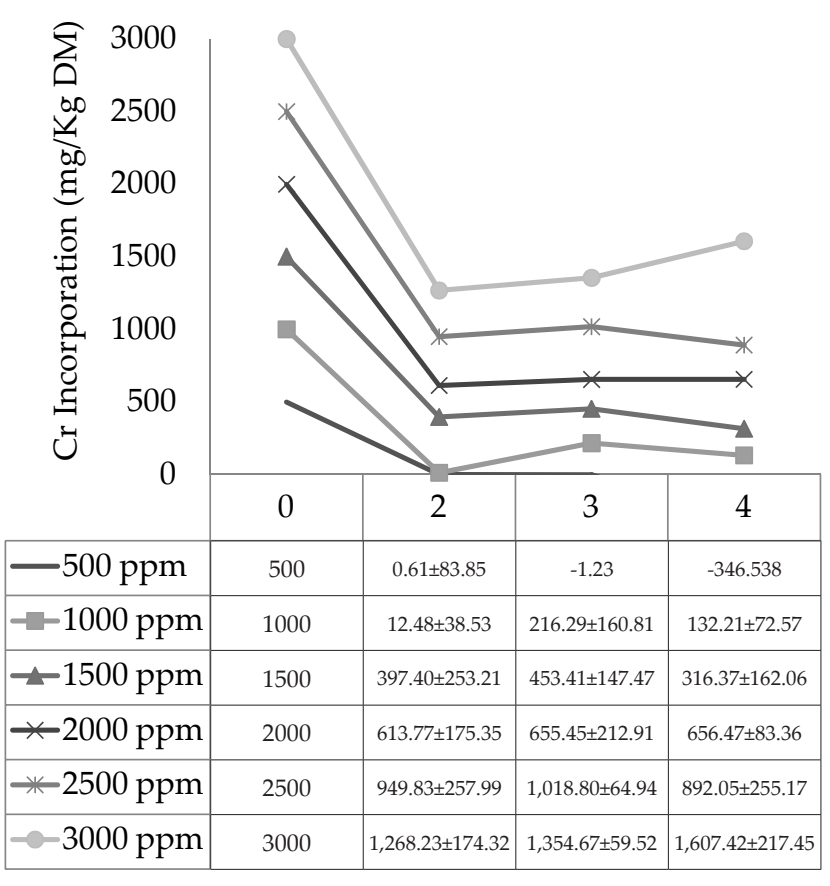

Fermentation time (wk)

Figure 3. Incorporation of $\mathrm{Cr}$ on Ganoderma lucidum cell in rice straw substrate with Cr levels $500(-), 1000(-*-), 1500$ $(-\bullet), 2000(-\bullet-), 2500(-x-)$, and $3000(-\square-)$ ppm and fermentation time 2, 3 and 4 wk.

contain more genes that can inhibit toxic metals (Sen \& Dastidar, 2010; Shugaba et al., 2012).

The highest $\mathrm{Cr}$ level supplemented into rice straw substrate was $3000 \mathrm{ppm}$. The highest $\mathrm{Cr}$ incorporation value was also found on substrate with $\mathrm{Cr}$ level of 3000 ppm (Figure 3). The element $\mathrm{Cr}$ was needed in the nutrient metabolism of carbohydrates and protein of $G$. lucidum cell for 4 weeks of fermentation. This indicates that G. lucidum was able to adapt to the medium with high levels of Cr. G. lucidum was also able to use the media components that are difficult to degrade.

G. lucidum was able to incorporate $\mathrm{Cr}$ into its cell proteins with the value of $9.29 \%$ (Table 3) when cultured in substrates containing 3000 ppm Cr. Some Cr was deposited in the neutral detergent fibre (NDF) $(27.20 \%)$ and acid detergent fibre (ADF) (10.55\%). These results showed that there has been a conversion of inorganic to organic forms of $\mathrm{Cr}$ by G. lucidum. Cr founded in the protein of G. lucidum cell is an organic compound.

The highest efficiency of $\mathrm{Cr}$ incorporation was 53.58\% showed in treatment with 3000 ppm $\mathrm{Cr}$ and fermentation time of 4 wk (Figure 3 ). It has been suggested that chromium ions can be incorporated into G. lucidum cells by two step, the first step involves the surface binding of $\mathrm{Cr}$ (III) ions to the cell wall and extracellular material, which is not depend on metabolism process. The second step is depending on the metabolic activity because uptake $\mathrm{Cr}$ (III) into the cell across the cell membrane and at that time is occurred intracellular accumulation (Sen \& Dastidar, 2010). 
Table 3. The number of $\mathrm{Cr}$ in fiber component and protein of Ganoderma lucidum fermentation product on rice straw containing 3,000 ppm $\mathrm{Cr}$ in the form $\mathrm{CrCl}_{3} \cdot 6 \mathrm{H}_{2} \mathrm{O}$

\begin{tabular}{lccc}
\hline \multicolumn{1}{c}{ Parameter } & $\begin{array}{c}\text { Dry matter } \\
(\mathrm{g})\end{array}$ & $\begin{array}{c}\text { Cr level } \\
(\mathrm{mg} / \mathrm{kg} \mathrm{DM})\end{array}$ & $\begin{array}{c}\text { Total Cr } \\
(\mathrm{mg})\end{array}$ \\
\hline Total products & 235.6 & 3030 & 714 \\
NDF & 173 & 1112 & 194 \\
ADF & 157 & 480 & 75 \\
NDF + ADF & 380 & 1592 & 269 \\
Protein & 0.895 & 74112 & 66 \\
\hline
\end{tabular}

\section{CONCLUSION}

The loss of dry matter and organic matter in fermented rice straw was related to the growth of mycelium of G lucidum. The binding of $\mathrm{Cr}$ occurs by fiber matrix of substrate. Inorganic $\mathrm{Cr}$ conversion into organic forms by fungi G. lucidum on rice straw substrate was evidenced by the presence of $\mathrm{Cr}$ in protein of fermented product. Protein component of fermented product contained $9.29 \% \mathrm{Cr}$ while in NDF and ADF was $27.20 \%$ and $10.55 \% \mathrm{Cr}$, respectively at level of $3000 \mathrm{ppm} \mathrm{Cr}$. Chromium was incorporated into the G. lucidum cells during fermentation and G. lucidum is tolerant of high Cr levels up to $3000 \mathrm{ppm}$.

\section{ACKNOWLEDGEMENT}

We gratefully acknowledge the financial support from (1) the Ministry of National Education, Directorate General of Higher Education for the Doctoral Scientific Research Fund of Bogor Agricultural University, Indonesia (2) the Department of Agriculture in KKP3T Project for financial support of this research.

\section{REFERENCES}

Agustin, F., T. Toharmat, D. Evvernie, D. Taniwiryono, S. Tarigan, \& I. Prihantoro. 2010. Chromium incorporation by Ganoderma lucidum with oil palm by-product as substrate. Med. Pet. 33: 18-24.

Agustin, F., D. Evvyernie., D. Taniwiryono, S. Tarigan, \& T. Toharmat. 2011. Milk yield and mastitis status of dairy cattle fed ration supplemented with chromium and Ganoderma lucidum. Indon. J. Nutr. Feed Sci. 2: 47-53.

Baldrian, P. 2003. Interaction of heavy metals with white-rot fungi. Enzyme Microb Technol 23:79-91.

Bradford, M. M. 1976. A rapid and sensitive method for quantitation of microgram quantities of protein utilizing the principle of protein-dye binding. Anal. Biochem. 72: 248254. http://dx.doi.org/10.1016/0003-2697(76)90527-3
Carry, E. E. \& W. H. Allaway. 1971. Determination of chromium in plants and other biological materials. J Agric Food Chem. 19:1159-1167. http://dx.doi.org/10.1021/jf60178a009

Chang, S. T. \& P. G. Miles. 2004. Mushrooms: Cultivation, Nutritional Value, Medical Effect, and Environmental Impact. $2^{\text {nd }} \mathrm{Ed}$. CRC Press. Boca Raton, London. http://dx.doi. org $/ 10.1201 / 9780203492086$

Erkel, E. I. 2009. The effect of different substrate mediums on yield of Ganoderma lucidum (Fr.) Karst. J. Food Technol. Biotechnol. 41: 371-382.

Ezzouhri, L., E. Castro, M. Moya, \& F. Espinola. 2009. Heavy metal tolerance of filamentous fungi isolated from polluted sites in Tangier. Morocco. Afr. J. Microbiol. 3: 35-48.

Ke, L., Q. Wu, \& D. Zhang. 2011. Bioconversion of rape straw into nutritionally enriched by Ganoderma lucidum and yeast. Afr. J. Biotechnol. 10: 1548-1558.

Misra, A. K, A. S. Mishra, M. K. Tripathi, R. Prasad, S. Vaithiyanathaan, \& R. C. Yalchmola. 2007. Optimization of solid state fermentation of mustard (Brassica campestriss) straw for production of animal feed by white rot fungi (Ganoderma lucidum). Asian-Aust J Anim Sci 20:208-213.

Mtui, G. Y. S. \& Y. Nakamura. 2007. Characteristic of lignocellulosic enzymes from white- rots fungus Philebia chrysocreus, isolated from a marine habitat. J. Eng. Appl. Sci. 2: 1501-1508.

Mtui, G. Y. S. 2012. Lignocellulolytic enzymes from tropical fungi: types, substrate and applications. Sci. Res. Essays. 7: 1544-1555.

[NRC] National Research Council, Committee on Animal Nutrition. 1997. The Role of Chromium in Animal Nutrition. National Academic Press, Washington DC.

Oliver, D. S., F. J. Brockman, R. S. Browman, \& T. L. Kieft. 2003. Microbial reduction of hexavalent chromium under vadose zona condition. J. Environ. Qual. 32: 319-324.

Pant, D., U. G. Reddy, \& A. Adholeya. 2006. Cultivation of oyster mushromm on wheat straw and bagasse substrate amended with distillery effluent. World J. Microbiol. Biotechnol. 22: 267-275. http://dx.doi.org/10.1007/s11274-0059031-2

Pechova, A. \& I. Pavlata. 2007. Chromium as an essential nutrient: a review. Vet. Med. 57:1-18

Prasenjit, B. \& S. Sumathi. 2005. Uptake of chromium by Aspergillus foetidus. J. Material Cycles and Waste Management. 7: 88-92. http://dx.doi.org/10.1007/s10163-005-0131-8

Sen, M. \& M. G. Dastidar. 2010. Chromium removal using various biosorbents. Iran J. Environ. Health Sci. 7: 182-190.

Shugaba, A., F. Buba, B. G. Kolo, A. J. Nok, D. A. Ameh, \& J. A. Lori. 2012. Uptake and reduction of hexavalent chromium by Aspergillus niger and Aspergillus parasiticus. J. Pet. Environ. Biotechnol. 3: 119-126. http://dx.doi.org/10.4172/21577463.1000119

Wagner, R., D. A. Mitchell, G. L. Sassaki, M. A. L. A. Amazonas, \& M. Berovi. 2003. Current techniques for the cultivation of Ganoderma lucidum for the production of biomass, ganoderic acids and polysaccharides. Food Technol. Biotechnol. 41: 371-383. 